\title{
ON THE DISTRIBUTION OF CONOCEPHALUM CONICUM AND $C$. SALEBROSUM (MARCHANTIOPHYTA) IN RUSSIA
}

\section{К РАСПРОСТРАНЕНИЮ CONOCEPHALUM CONICUM И C. SALEBROSUM (MARCHANTIOPHYTA) В РОССИИ}

\author{
E.A. BOROVICHEV ${ }^{1}$, N. KALINAUSKAITË ${ }^{2} \&$ N.A. KONSTANTINOVA ${ }^{1}$ \\ Е.А. БОРОВИЧЕВ ${ }^{1}$, Н. КАЛИНАУСКАЙТЕ ${ }^{2}$, Н.А. КОНСТАНТИНОВА ${ }^{1}$
}

Abstract

The Conocephalum conicum-group is revised in Russia basing on the narrow species concept. A key to species of the genus Conocephalum, illustrations, and a comparison of C. conicum (L). Dumort. with C. salebrosum Szweyk., Buczk. \& Odrzyk. are given. On the base of the revision of 243 samples the distribution of both taxa in Russia is given.

Резюме

Проведена ревизия видов, входящих в комплекс Conocephalum conicum в соответствии с современным пониманием их объема. На основе изучения образцов (243) с территории России уточнено распространение C. conicum (L). Dumort. s.str. и C. salebrosum Szweyk., Buczk. \& Odrzyk. Приведены основные диагностические признаки, а также рисунки этих видов, дан ключ для определения видов рода Conocephalum в России.

KEYWORDS: Conocephalum conicum, Conocephalum salebrosum, Hepaticae, Russia, taxonomy

\section{INTRODUCTION}

Conocephalum salebrosum Szweyk., Buczk. \& Odrzyk. was recently described by Szweykowski et al. (2005). Among 324 specimens studied by authors of description, two specimens from Russia were identified as C. salebrosum (from Far East and Kaliningrad Province). After this publication $C$. salebrosum was recorded from several provinces of central and northern parts of european Russia (Borovichev \& Kokoshnikova, 2008; Borovichev \& Konstantinova, 2009; Dulin, 2008; Potemkin \& Kotkova, 2008; Potemkin et al., 2008). However, the current distribution of C. salebrosum and C. conicum (L). Dumort. s. str. in Russia remains poorly known. We studied specimens of Conocephalum conicum-group in KPABG, LE, MHA, PZV, H, TUR and OULU. Altogether 243 specimens were revised, revealing the ecology and distribution as well as morphological variability of two species in their current circumscriptions.

\section{DISCUSSION}

As it was stressed by Szweykowski et al. (2005), the distinction of $C$. conicum and $C$. salebrosum is complicated. The best diagnostic feature is the structure of pores of the archegoniophore «head», but the latter are rarely present among revised specimens. The most important characters of sterile plants are: the structure of dorsal thallus surface including limits between particular air chambers and texture of the dorsal surface of the thallus; the number of air

1 - Polar-Alpine Botanical Garden, Kola Sci. Center of Russian academy of Scienses, Kirovsk-6, Murmansk Province 184256 Russia - Россия 184256, Кировск-6 Мурманской области, Полярно-альпийский ботанический сад-институт КНЦ РАН; e-mail: borovichev@yandex.ru \& nadya50@mail.ru

2 - Botanical Museum University of Helsinki, P.O. Box 7 FIN-00014 Helsinki, Finland; e-mail: kalinaus@mappi.helsinki.fi 
chambers between costa and margin of the thallus; the number of rows of hyaline cells at the margin of the thallus; the junction of air chamber wall with dorsal epidermis and the shape of hyaline apical cells underlying the pores. However the broad variability of these characters was found by Szweykowski et al. (2005) as well as in the present study (Table 1).

The feature of the thallus that allows to identify samples in the field is the structure of dorsal thallus surface. Microscopically the most useful are the width of hyaline margin of the thallus (in C. conicum (2-)3-4(-5) rows of elongated hyaline cells and in C. salebrosum 1-2 rows, sometimes lacking) and junction of air chamber wall with dorsal epidermis (in C. conicum the highest cell of air chamber wall reaches dorsal epidermal cells but is not inserted between them and in C. salebrosum the highest cell of air chamber wall is inserted between dorsal epidermal cells, cf. Figs. 1-5 and 1-11) are most reliable. The number of air chambers between costa and thallus margin (in $C$. conicum (3-)5-7(-9) and in C. salebrosum (3-)4-5(-7) and shape of the hyaline apical cells underlying the pores have very low diagnostic significance. Variability of two taxa based on Szweykowski et al. (2005) and our study are shown in more details in the Table 1.

\section{KEY TO SPECIES OF CONOCEPHALUM IN RUSSIA}

1. Thallus two to three times dichotomically branching, 1-3(-5) cm long and 3-6 mm wide; brown-green to pale brown-yellow, in the autumn becoming yellow-brown and even whitish; pores ellipsoidal; hyaline apical cells of assimilators under stomata finger-shaped; Far East ...... C. japonicum (Thunb.) Grolle

1. Thallus dichotomically branched, (1-)2-10(20) $\mathrm{cm}$ long and 5-30 mm wide; pores rounded; yellowish-green or aeruginose to dark; hyaline apical cells of assimilators under stomata flask-shaped or pyriform 2

2. Dorsal surface of thallus indistinctly reticulate; outer epidermal cell walls slightly inflatedflat; highest cells of air chamber walls usually not inserted into epidermal layer; hyaline margin of thallus broad, usually consisting of (2-) 3-4(-5) cell rows C. conicum
2. Dorsal surface of thallus distinctly reticulate; outer epidermal cell walls distinctly inflated, giving epidermis verrucose appearance; highest cells of air chamber walls inserted between epidermal cells; hyaline margin of thallus narrow, usually consisting of 1-2 cell rows or sometimes lacking.. C. salebrosum

\section{DISTRIBUTION AND ECOLOGY}

According to Szweykowsky \& al. (2005), C. salebrosum is a holarctic species occurring in Europe, East Asia and North America, whereas C. conicum is considered to be restricted to Europe only.

According to our data $C$. conicum is more widespread. It was found in Urals and in mountains of South Siberia, but eastwards of Baikal area (Khamar-Daban Range) it was not registered yet. All records of this species from the Russian Far East apparently should be referred to C. salebrosum. In European Russia C. conicum was collected in 8 of 51 administrative units and seems to be less frequent than C. salebrosum, which was registered in 26 of 51 provinces of European part of Russia. In spite of quite a large number of specimens studied it is difficult to find out differences in distribution patterns of these species in Europe. According to our data, C. salebrosum penetrates to more northern areas, e.g. in Arctic in Nenets Autonomous Distict, whereas the most northern locality of C. conicum is restricted to Subarctic (Murmansk Province).

In mountains, $C$. conicum was not found above $1080 \mathrm{~m}$ evel., and more often it has been collected below $600 \mathrm{~m}$. At the same time, C. salebrosum is known at higher elevations: e.g. in Caucasus it reaches $2100 \mathrm{~m}$, although more frequently occur between 400 and $1500 \mathrm{~m}$. So, $C$. salebrosum can be characterized as an arcto-boreal circumpolar species, whereas $C$. conicum is predominantly a boreo-temperate euro-siberian element.

Ecological preferences of both species are quite similar, moreover, they can grow intermingled (such specimens are marked in the list of specimens by asterisk, *). Both species occur as extensive mats along stream sides, bases on moist rocks and cliffs occupying sometimes several square meters. They grow on different substrates including soil, rocks, fine earth and 

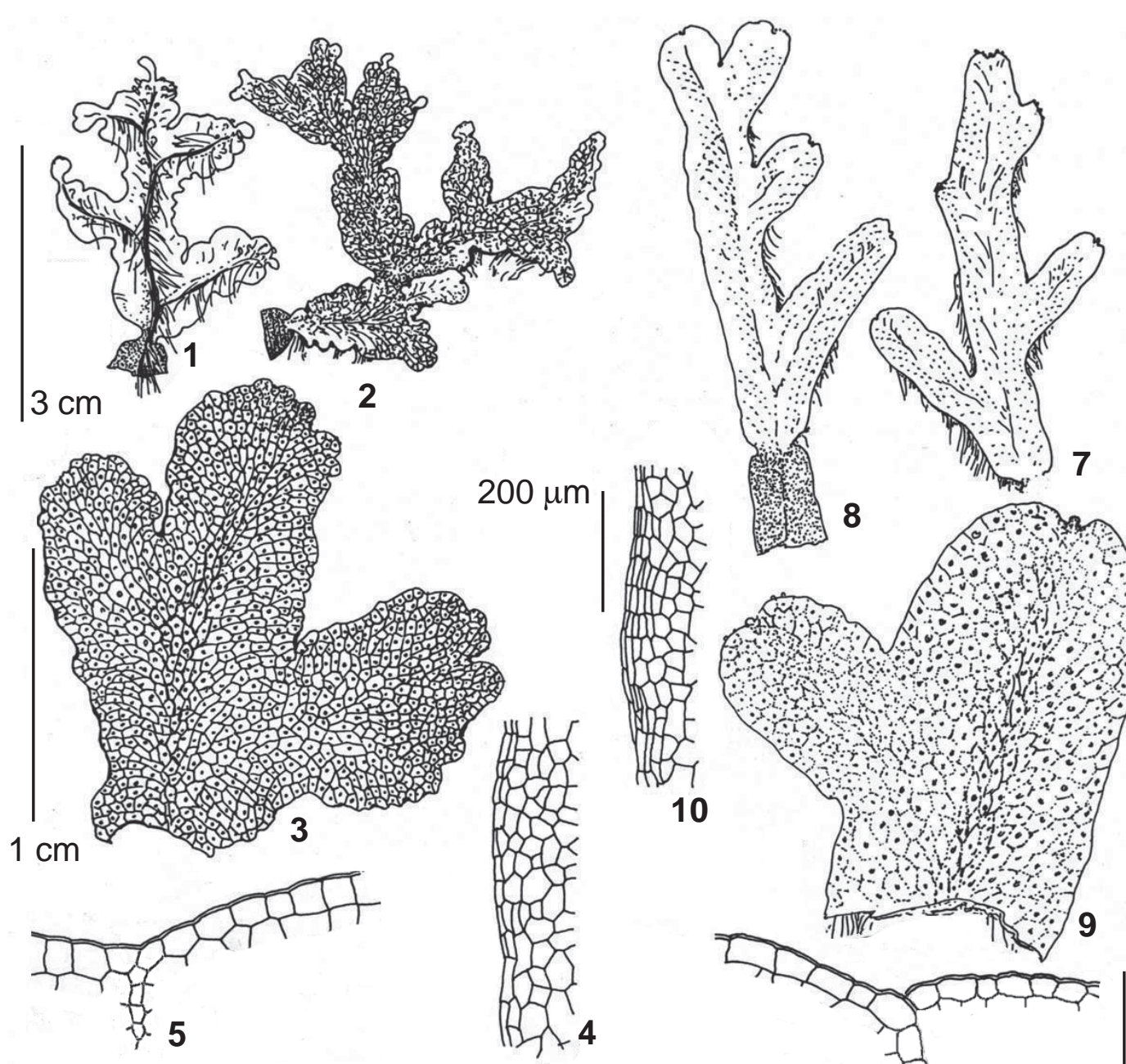

10
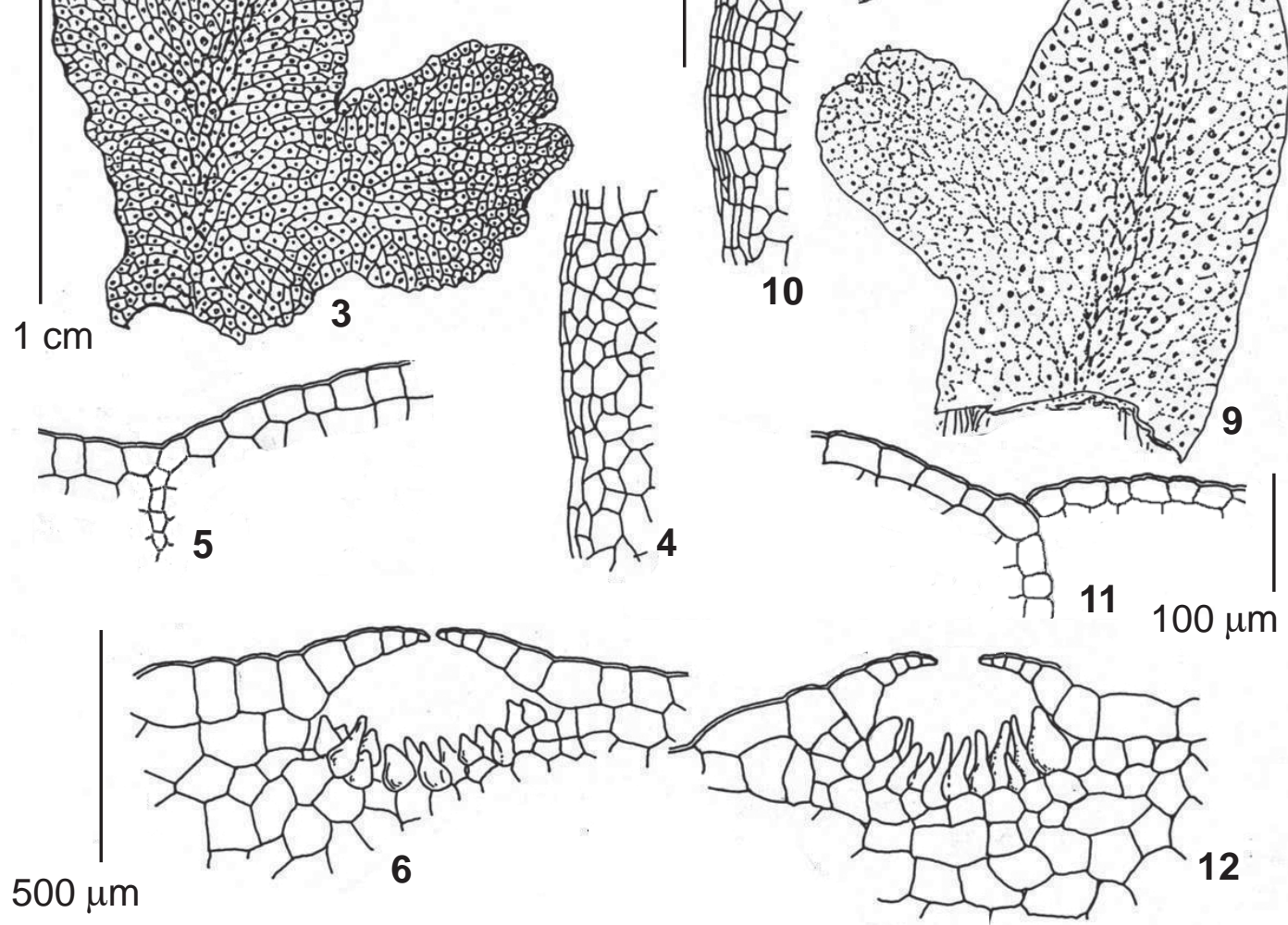

Fig. 1. Diagnostic characters of sterile thallus of Conocephalum salebrosum Szweyk., Buczk. \& Odrzyk. (1-6) and C. conicum (L.) Dumort. (7-12). 1,2,6,7 - habit; 3, 8 - texture of thallus dorsal surface; 4, 9-hyaline margin of thallus; 5,10 - junction of air chamber wall with epidermis; 6,12 - shape of the hyaline apical cells underlying the pores. Scale bars: $3 \mathrm{~cm}$ for $1,2,6,7 ; 1 \mathrm{~cm}$ for 3,$8 ; 500 \mu \mathrm{m}$ for 6,$12 ; 200 \mu \mathrm{m}$ for 4,$10 ; 100 \mu \mathrm{m}$ for 5,11 .

decaying wood. Both species prefer soils rich in humus and high $\mathrm{pH}$, but $C$. conicum seems to be more strongly restricted to calcareous substrates. It occupies large areas on cliffs in deep canyons, especially near waterfalls, whereas $C$. salebrosum grows in less shaded habitats and often occurs near springs and streams. Szweykowski et al. (2005) indicated that C. salebrosum is more tolerant to desiccation than $C$. conicum. 
Selected specimens examined: $*$ - mixed collections of both species; $\mathrm{S}+-$ specimens with archegoniophores.

\section{Conocephalum conicum}

EUROPEAN RUSSIA: NW Murmansk Prov.: Pechenga River, 6.VIII.1936 Häyren E. (H); Ponoy, 3.VIII.1972 Schlyakov R.N. (KPABG 5632); Lapland State Reserve, Sal'nye Mnts., 28.VII.2007 Borovichev (KPABG 18154); Kutsa Sanctuary, VIII.1986 Konstantinova (KPABG 5635, 5636*); Republic of Karelia: Louchskij Disct., Paanajarvi National Park, 26.VII.1998 Bakalin V.A. (KPABG 109387); Suojarvi Disct., 16.VIII.1939 Tuomikoski R. (H); Pudozhskij Disct., 27.IV.2002 Bakalin (KPABG 102569*); Petrozavodsk, 12.V.1998 Bakalin V.A., Bakalina L.N. [Bryophyta Karelica Exsiccata, 1998, \# 3] (KPABG 112316); NE Arkhangelsk Prov.: Pinega State Reserve, 7.VIII.1988 Ignatov M.S. (MHA); $\underline{\mathrm{C}}$ Moscow Prov., Zagorskij Disct., 25.VII.1985 Ignatov (MHA); Ruzskij Disct., 16.V.1984 Ignatov (MHA*); Serpukhovskij Disct., Priokscko-Terrasnyj State Reserve, 22.IX.1987 Ignatov (MHA); Republic of Mari-El: Bol'shay Kokshaga State Reserve, 16.IX.2004 Konstantinova (KPABG 108097); N-Ur Republic of Komi: TroitskoPecherskij Disct., 18.VI.1985 Zheleznova (KPABG 100729); Perm‘s Prov.: Basegi State Reserve, IX.2004 Konstantinova (KPABG 108401); CAUCASUS: Krasnodar Territory: Tuapse Disct., Tuapse 12.IX.1995 Kostyleva N.V. $\left(\mathrm{MHA}^{*}\right)$; Caucasian State Reserve, IX.2008 Konstantinova (KPABG 100885*, 112838, 112768); 19.09.2009 Konstantinova, Savchenko (KPABG K-116-09*), 4.10.2009 Konstantinova, Savchenko (KPABG K-177-2-09s ${ }^{+}$); SIBERIA: SIBS Republic of Altai: Kayra River, 18.VII.1993 Ignatov (MHA 35-55); Republic of Tuva: Todzha Valley, VII.1999 Bakalin (KPABG 100885, 100841); Republic of Buryatya: Khamar-Daban Ridge, Baikalskij State Reserve, 8.VIII.2001 Konstantinova (KPABG 102448, 109897*).

\section{Conocephalum salebrosum}

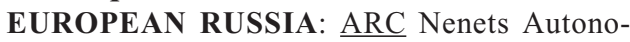
mous Area: North Timan, 18.VIII.2008 Dulin (KPABG 112315); NW Murmansk Prov.: Rybachij Peninsula, 17.VII.1978 Konstantinova (KPABG 5630); Pechenga River 3.VII.1938 Alava R. (H; TUR 031459); Lapland State Reserve, Sal'nye Mts., VIII.2007 Borovichev (KPABG 18380); Kutsa Sanctuary, Pyhukuru, Konstantinova (KPABG 5636*); Republic of Karelia: Louchskij Disct. Paanajarvi National Park, 23.VIII.1933 Kotilainen M. (H); Kaleval'skij Disct., 16.VII.1998 Bakalin (PTZ); Pudozhskij Disct. 27.IV.2002 Bakalin V.A. (KPABG 102569*); Petrosavodsk, 16.X.2005 Maksimova, Maksimov (PTZ 05-11); Leningrad Prov.: St. Peters- burg, conservatory of Botanical Institute RAS, 29.V.1932 Ladyzhenskaja K.I. (LE); Podporozhskij Disct., 23.IV.1943 Ruotsalo R. $\left(\mathrm{H}^{\mathrm{s}}\right)$; Luzhskij Disct.,11.VIII.1926 Ganeshin S.S. (LE); Volosovskij Disct., 14.V.1985 Ignatov (MHA); NE Arkhangelsk Prov.: Holmogorskij Disct., 28.V.1917 Savich L.I., Savich V.P. (LE); Pinegskij State Reserve, 30.VII.1988 Ignatov (MHA); KLN Kaliningrad Prov: 24.VII.1907 Mikutowicz J. (H); $\underline{\mathrm{C}}$ Vologda Prov.: Belozerskij Disct., 14.VII.1956 Metelkova T.A. (H 3169756, LE); Sokol Disct., 22.IX.1990 Ignatov (MHA); Novgorod Prov.: Perevozskij Disct., 15.VIII.1937 Smirnova A. (LE); Valdajskij Disct., 4.V.1980 Morozova O.V. (MHA); Pskov Prov.: Dnovskij Disct., 3.V.1940 Abramov I.I. (LE), 31.V.1940 Abramova A.A. (LE); Tver Prov.: 26.VI.1923 Andreev V.N. (LE); Nizhnij Novgorod Prov.: Lubitinskij Disct., 13.IX.1957 Kil'dushevskij I.D. (LE); Vladimir Prov.: Gorochoveckij Disct., VI.2007 Kokoshnikova Y.S. (KPABG 112312); Melenkovskij Disct., 8.V.2008 Kokoshnikova (KPABG 112313); Voronezh Prov.: Semilukskij Disct., 18.IX.1989 Popova N.N. (LE); Moscow Prov.: Park Filevskij, 2.V.1985 Ignatov $\left(\mathrm{MHA}^{\mathrm{s}}\right)$; Dmitrovskij Disct., 14.V.1986 Ignatov (MHA); Ruzskij Disct., 16.V.1984*, 25.IV.1985 Ignatov $\left(\mathrm{MHA}^{\mathrm{s}}\right)$; Serpukhovskij Disct., Priokscko-Terrasnyj State Reserve, 18.VI.1996 Ignatov (MHA); Kursk Prov.: Oboyan Disct., Centralno-Czernozemnyj State Reserve, 20.V.1999 Ignatov (MHA); Kirov Prov.: Nolingskij Disct., 22.VII.1925 Razumin M. (LE); Republic of Tatarstan: Kazan', 4.VIII.1882 Krylov P.N. (LE); Volzhsko-Kamskij State Reserve, 4.X.2004 Ignatov, Ignatova (MHA 05-2242); N-UR Republic of Komi: Vorkutinskij Disct., 1.VII.2008 Dulin (112055); Troitsko-Pecherskij Disct. 10.VI.1985, Zheleznova (KPABG 100529); Perm‘s Prov.: Kudymkarskij Disct., 1932 Vasil'eva (LE); Vishera State Reserve, 11.VII.2004 Konstantinova (KPABG 108114); Basegi State Reserve, IX.2004 Konstantinova (KPABG 108294); S-UR Republic of Bashkortostan: Byrzyan Disct., 10.IX.1990 Ignatova (MHA 11-78); SE Samara Prov.: Volzhskij Disct., 21.VII.1926 Stunkenberg E.Yu., Zhigulevskij State Reserve, 27.V.1928 Sprigin I. (LE); CAUCASUS: Republic of Kabardino-Balkaria: Belaya River, 25.VIII.2005 Ignatov, Ignatova, Kharzinov. (MHA 05-1790); Dumala River, 21.VIII.1987 Portenier N.N., Portinier E.B. (MHA); Republic of Karachaevo-Cherkessia: Teberda State Reserve, IX.2005 Konstantinova (KPABG 109729); Krasnodar Territory: Anapa Disct., Malyj Utrish Surroundings, 4.V.2005 Ignatov, Ignatova (KPABG 109429); Tuapse Disct., Tuapse, 12.IX.1995 Kostyleva (MHA*); Caucasian State Reserve, Chosta Branch, 12.VIII.2002 Ignatov, Ignatova. (KPABG 
Table 1. Comparison of Conocephalum conicum and C. salebrosum (\# - after Szweykowski et al., 2005)
Character
C. conicum
C. salebrosum

\section{Dorsal surface of thallus}

Colour yellowish-green, sometimes aeruginosus yellowish-green to dark-green, sometimes

purplish

Shine glossy dull

Borders between inconspicuous conspicuous

air chambers

Junctions of air on the same levels with thallus surface in shallow depressions in thallus

chambers

Reticulation not clear

Outer epidermal slightly inflated

cell walls

Junction of air highest cell of air chamber wall reaches chamber wall with dorsal epidermal cells but is not

dorsal epidermis inserted between them

Number of rows (2-)3-4(-5) / [3-4]

of hyaline cells at

margin of thallus

Margin of thallus plane or rarely recurved

Number of air $\quad 5-7(-9) /[6-8 \text {, rarely less }]^{\#}$

chambers between

costa and margin

\section{Ventral surface of thallus}

Colour of
ventral surface

Colour of rose to reddish-brown, rarely colourless more or less reddish-brown

ventral scales

Colour of rhizoids whitish to reddish

frequently milky-white

Stomata of

\section{Archegoniophore $^{\#}$}

«head», $\mu \mathrm{m} \quad 66-121 \times 33-77$

$99-165 \times 44-88$

Lowest cells of

stomata of «head» relatively short and variously oriented

Epidermis of air

chamber

bistratose

elongate and arranged parallelly to long axis of stomatal apparatus, forming rather distinct fascicle

112839*, 112840); Guzeripl, X.2007 Konstantinova (KPABG 111734); SIBERIA: SIB-S Republic of Altai: Teletzkoe Lake, Koldor, Bolschoj Istube River, 26.IV.1977 Zolotukhin N.I. $\left(\mathrm{MHA}^{\mathrm{s}}\right)$; Samysch River, 26.IV.1977 Zolotukhin $\left(\mathrm{MHA}^{\mathrm{s}}\right)$; Bolschoj Schaltan River, 7.VI.1989 Zolotukhin $\left(\mathrm{MHA}^{\mathrm{s}}\right)$; Republic of Tuva: Todzha Valley, 13.VII.1999 Bakalin (KPABG 100890, 100885*); Republic of Buryatia: Khamar-Daban Ridge, Baikalskij State Reserve, VIII.1999 Bakalin (KPABG 109897*, 102856); FAR EAST: KAM Kamchatka Prov.: northern Kamchatka, 14.VII.2003
Bakalin (KPABG 105408); central Kamchatka, 28.VIII.2001 Bakalin (KPABG 103901); southern Kamchatka, 22.VIII.2001 Bakalin (KPABG 103787); Eastern of Kamchatka, 23.V.2004 Bakalin (KPABG $107806^{\text {s+ }}, 107811^{\text {st }}$ ); Commander Archipelago: Mednij Islands, 1.VII.2004 Bakalin (KPABG 106678); Northern Kurils: Paramushir Islands, VII.2004 Bakalin (KPABG 107433); AMU Khabarovsk Territory: Ul'chskij Disct., 3.IX.1976 Alanko P. (H), Khabarovskij Disct., 11.IX.1976 Alanko (H); SAKH Sakhalin Prov.: South Sakhalin, VII.2001 Harpel J.A., 
Cherdantseva V.J (KPABG 105797); S-KUR Kunaschir Islands, 10.IX.1988 Zolotukhin (MHA); PRIM Primorskij Territory: Vladivostok, 2.10.1985 Ignatov (MHA); Schkotovskij district, 7.X.1995 Konovalova \& al. (MHA); Khasanskij Disct., «Kedrovaja Pad» State Reserve, X.1977 Ignatov (MHA).

\section{ACKNOWLEDGEMENTS}

Authors sincerely acknowledge to the curators of H, LE, MHA and PZV for the possibility to work in herbariums and for the loan of Conocephalum specimens. Special thanks to Dr. T.Ulvinen for supplying material from TUR and OULU. This research was supported by the Russian Foundation for Basic Research, grants \#\# 09-04-00281, 09-04-10078.

\section{LIETRATURE CITED}

[BOROVICHEV, E.A. \& YU.S. KOKOSHNIKOVA] БОРОВИЧЕВ Е.А., Ю.С. КОКОШНИКОВА 2008. НовЫе находки печеночников во Владимирской области. 1. [New liverwort records from Vladimir Province. 1] Arctoa 17: 206-207.
[BOROVICHEV, E.A. \& N.A. KONSTANTINOVA] БOPOВИЧЕВ Е. А., Н.А. КОНСТАНТИНОВА 2009. Род Сопоcephalum Wigg. в Мурманской области [Genus Conocephalum Wigg. in Murmansk Province] В кн.: Биологическое разнообразие северных экосистем в условиях изменяюшегося климата (Тезисы докладов межсународной научной конференции). Anатиты [In: Biological Diversity of the Northern Ecosystems Under Changeable Climate (Abstracts International Science Conference). Apatity]: 6-7.

[DULIN, M.V.] ДУлИН, M.B. 2008 Новые находки печеночников в республике Коми. 2. - [New liverwort records from Komi Republic. 2] Arctoa 17: 200-201.

POTEMKIN, A.D. \& V.M. KOTKOVA 2008. New liverwort records from Republic of Karelia. 1. - Arctoa 17: 191-192.

POTEMKIN, A.D., V.M. KOTKOVA \& E.V. KUSHNEVSKAYA 2008. New liverwort records from Leningrad Province. - Arctoa 17: 194-195.

SZWEYKOWSKI, J., K. BUCZKOWSKA \& I.J. ODRZYKOSKI 2005. Conocephalum salebrosum (Marchantiopsida, Conocephalaceae) - a new Holarctic liverwort species. Pl. Syst. Evol. 253: 133-158. 